University of South Carolina

Scholar Commons

1999

\title{
Effects of Competition on Resource Availability and Growth of a California Bunchgrass
}

Andrew R. Dyer

University of South Carolina - Aiken, AndyD@usca.edu

Kevin J. Rice

University of California - Davis

Follow this and additional works at: https://scholarcommons.sc.edu/aiken_biology_geology_facpub

Part of the Biology Commons, Botany Commons, and the Weed Science Commons

\section{Publication Info}

Published in Ecology, Volume 80, Issue 8, 1999, pages 2697-2710.

(C) 1999 by the Ecological Society of America

Dyer, A., \& Rice, K. (1999). Effects of Competition on Resource Availability and Growth of a California Bunchgrass. Ecology, 80(8), 2697-2710. https://doi.org/10.1890/0012-9658 inclusion in Faculty Publications by an authorized administrator of Scholar Commons. For more information, please contact digres@mailbox.sc.edu. 


\title{
EFFECTS OF COMPETITION ON RESOURCE AVAILABILITY AND GROWTH OF A CALIFORNIA BUNCHGRASS
}

\author{
ANDREW R. DYeR ${ }^{1,3}$ AND KEVIN J. RicE ${ }^{2}$ \\ ${ }^{1}$ Graduate Group in Ecology, University of California, Davis, California 95616 USA \\ ${ }^{2}$ Department of Agronomy and Range Science and Center for Population Biology, University of California, \\ Davis, California 95616 USA
}

\begin{abstract}
In California, little is known about the sensitivity of native bunchgrasses to competition or to changes in resource availability. We investigated the effect of nonnative annual vegetation on resource availability and growth of a native bunchgrass, Nassella pulchra, in a pair of factorial field experiments that incorporated effects of both interspecific and intraspecific competition as well as variation in soil depth. Plots of differing target densities and neighborhoods were used to assess changes in aboveground (light) and belowground (water) resource availability over multiple seasons in two sites with differing soil depth. N. pulchra grown without interspecific competitors grew larger and produced more culms at all planting densities compared to plants in plots with interspecific competitors. Intraspecific competition significantly influenced growth only in the absence of interspecific competition. Reproductive effort, as measured by flowering culm production, was more sensitive than vegetative growth to both forms of competition. Light availability and variability at the soil surface was greatly reduced by the nonnative annual neighborhood. As expected, soil moisture was rapidly depleted by annuals to $30 \mathrm{~cm}$ in all plots. In deepsoil plots, soil moisture was reduced at $60-150 \mathrm{~cm}$ depths only when annual vegetation was removed, and depletion was correlated with $N$. pulchra basal area. This result suggests that the interspecific neighborhood reduced root growth in $N$. pulchra and its subsequent ability to use deep moisture. Within California's inland grasslands, nonnative annual vegetation has changed seasonal patterns of resource availability. We conclude that (1) increased competition for light during the spring, when growth of annuals is most rapid, suppresses growth and reproduction of N. pulchra; (2) by suppressing bunchgrass growth, annual grasses reduce access to belowground resources by competitive interference; and (3) the loss of perennial grasses in California grasslands and the general dominance by nonnative annual species results in the relative underutilization of deep soil resources. These conclusions suggest that the dominance of California grasslands by nonnative annual vegetation has shifted the primary limiting resource from soil moisture to light and the timing of resource limitation from summer to winter and spring.
\end{abstract}

Key words: bunchgrass; California grasslands; competition; density dependence; grasses, annual; grasses, perennial; interference; invasive species; Nassella pulchra; resource limitation; soil moisture depletion.

\section{INTRODUCTION}

Disentangling the many factors responsible for the type-conversion of California grasslands since the arrival of European settlers $\sim 230 \mathrm{yr}$ ago has not been easy (Bartolome and Gemmill 1981, Heady 1988, Stromberg and Griffin 1996, Dyer and Rice 1997). However, the outcome of the conversion process is an ecosystem with potentially very different properties that is now dominated by annual species, especially grasses, rather than perennial grasses (Talbot et al. 1939, McNaughton 1968, Heady 1988). Other examples of native ecosystems invaded by highly compet-

Manuscript received 26 January 1998; revised 21 September 1998; accepted 29 September 1998; final version received 16 November 1998.

${ }^{3}$ Current address: Department of Biology, University of Michigan, Ann Arbor, Michigan 48109 USA.

E-mail: ardyer@bigfoot.com itive or disturbance-oriented plant species demonstrate significant changes to community structure as well as changes in the size of resource pools and overall resource availability (Vitousek 1986, 1990, D’Antonio and Vitousek 1992).

To understand competitive mechanisms in the annual grassland or in any plant community, it is important to consider that resource levels are spatially and temporally heterogeneous and that numerous physical and biotic processes limit the availability of resources such as light, water, and nutrients (Weaver and Rowland 1952, Newman 1973, Grime 1979, Knapp and Seastedt 1986, Tilman 1988). In turn, the relative availability of aboveground and belowground resources will influence the rate of plant growth and the intensity of competitive relationships (Newman 1973, Grime 1979, Aarssen 1983, Tilman 1988, Keddy 1989, Goldberg 1990). The resulting interaction between the above- 
ground and belowground resource pools is modulated by the type and structure of the neighborhood surrounding the individual plant (Fowler 1986, Gurevitch 1986, Goldberg 1987, Miller and Werner 1987, Goldberg and Landa 1991). Thus, the competitive effect of the plant community on an individual is an integration of interspecific effects, intraspecific effects, and the associated interactions (Goldberg 1994).

Belowground resource availability in mediterranean climates is strongly dependent on seasonal rainfall patterns (Gulmon et al. 1983, Jackson and Roy 1986, Jackson et al. 1988, Kadmon and Shmida 1990a, b). Moreover, plant-plant interactions are strongly influenced by the timing and pattern of precipitation events (Rice 1989, Goldberg and Novoplansky 1997) that affect total productivity and soil moisture reserves (Kay and Owen 1970, Evans and Young 1989). Soil moisture availability is further influenced by soil quality and depth (Van Auken et al. 1994, Belcher et al. 1995, Turitzen 1995). In inland California, the highly seasonal distribution of precipitation, for many species, is out of phase with light availability and favorable growing temperatures (Major 1988). A nearly complete lack of precipitation during the period of highest potential evapotranspiration has resulted in a grassland flora dominated by species that specialize, in general, in one of two life history strategies. Cool-season annual species maximize aboveground growth at the expense of resource use efficiency (Jackson and Roy 1986) and senesce by late spring/early summer. In contrast, perennial species and warm-season annual species allocate more biomass to efficient belowground resource acquisition (Jackson and Roy 1986, Holmes and Rice 1996) and can continue to grow into, and often throughout, the dry summer months (Major 1988).

In this study, we attempted to quantify the interaction between seasonal resource availability and the competitive effects of nonnative annual vegetation on a native bunchgrass. We used a common native bunchgrass, Nassella pulchra (Hitchc.) Barkworth (formerly Stipa pulchra Hitchc.), as a phytometer for measuring growth over multiple growing seasons. We chose two sites with potentially similar aboveground conditions for experimentation, but one site had very restricted rooting depth and one had unlimited rooting depth.

To understand better the dynamics and consequences of competition between nonnative annuals and N. pulchra, we addressed the following questions: (1) What is the effect of the nonnative annual vegetation (specifically, grasses) in the California grassland on growth and reproduction in $N$. pulchra, a formerly widespread native bunchgrass? (2) Because annual biomass has been correlated with increased mortality rates of mature N. pulchra (Dyer and Rice 1997), what are the relative effects of annuals on resource availability both within and between growing seasons? (3) Is the response of $N$. pulchra to annuals a density-dependent function and does the relationship depend on soil depth? Given the high densities and nearly ubiquitous distribution of many annuals in the California grasslands, we discuss the implications of our results for the future management of native species within this system.

\section{Study Sites}

The Agronomy Farm (deep-soil site) was located on the University of California, Davis campus $\left(38^{\circ} 33^{\prime} \mathrm{N}\right.$, $121^{\circ} 48^{\prime} \mathrm{W}$ ) in Yolo County, California, and was characterized by Reiff loam, a Class 1 recent alluvial soil (coarse-loamy, mixed, nonacid, thermic Typic Xerofluvent) (Huntington et al. 1981). The plots were placed in a weedy old field, undisturbed since 1986, dominated by dense stands of the nonnative annual grasses Bromus diandrus Roth., B. hordeaceus L., and Hordeum murinum L. Nomenclature follows Hickman (1993).

The second site was $25 \mathrm{~km}$ southwest at the Jepson Prairie Reserve (shallow soil site) $\left(38^{\circ} 20^{\prime} \mathrm{N}, 121^{\circ} 50^{\prime}\right.$ $\mathrm{W})$ in Solano County, California. The area is characterized by "mima mound" topography (Holland and Jain 1988) and is underlain by a clay layer impervious to percolation and plant roots at a depth of $\sim 20 \mathrm{~cm}$ in intermound areas and $\sim 65 \mathrm{~cm}$ under mounds. The underlying clay creates a perched water table during winter and spring that results in a seasonally wet, "vernal pool" environment in the lowest intermound areas (Holland and Jain 1988). The soil at the Jepson Prairie is classified as San Ysidro sandy loam (fine, montmorillonitic, thermic, Typic Palexeralf) (Bates 1977). Study plots were placed in an area that had been moderately and seasonally grazed by sheep for several decades and with no recent history of fire. The vegetation on the mounds was dominated by nonnative grass species, such as B. diandrus, B. hordeaceus, and $H$. $m u$ rinum with lower densities of other species including Erodium sp. and native annual dicots. There were higher proportions of the nonnative $B$. hordeaceus, H. marinum Hudson and Vulpia bromoides (L.) S. F. Gray in the intermound areas than on the mounds. A rhizomatous, native, perennial grass, Distichlis spicata (L.) E. Greene, is common throughout Jepson Prairie and roots of this species probably occurred in all plots, although it comprised a very small percentage of the total plant cover. The native bunchgrass, Nassella pulchra (see Plate 1), is common throughout the Jepson Prairie (see Dyer and Rice 1997), but does not occur on the Agronomy Farm.

The climate at the study sites is typically mediterranean with most preciptitation in winter and early spring (Major 1988). Average annual precipitation for Davis, California, is $435 \mathrm{~mm}$ (75-year average); during this study the precipitation was $753 \mathrm{~mm}$ in 1993, 301 $\mathrm{mm}$ in 1994, and $793 \mathrm{~mm}$ in 1995. Based on the seasonal distribution of precipitation events, these years were considered wet, dry, and very wet years. Actual evapotranspiration is at a maximum in April-May and usually exhausts soil moisture reserves in the upper soil layers by the end of June (Major 1988). 
Plate 1. Mature Nassella pulchra (purple needlegrass) at Jepson Prairie. Note the high density of neighboring annual grasses typical of inland California grasslands. Photo by Robert Langstroth.

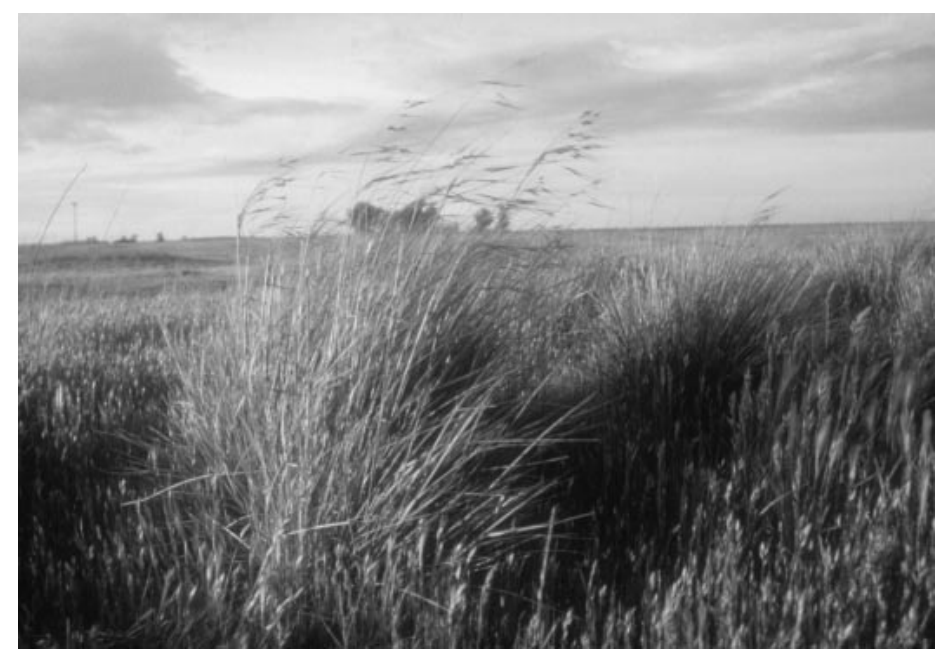

\section{Methods And Materials}

Plant materials and experimental design

Nassella pulchra is a caespitose, nonrhizomatous, long-lived species (Bartolome and Gemmill 1981) and was probably much more abundant in many California grasslands prior to European settlement. It is currently distributed throughout lower elevation ranges from the California coast to the Sierra Nevada foothills and generally on nonarable lowland soils or foothill range lands (Huenneke 1989). All target plants in this study were grown from seed collected the previous year at Jepson Prairie, germinated and grown for $2 \mathrm{mo}$ in $2.5 \mathrm{~cm} \mathrm{di}-$ ameter by $15 \mathrm{~cm}$ long plastic tubes under glasshouse conditions, and cold-hardened before planting in the field. Potting soil residue was washed from the roots of each seedling prior to transplanting. Plants that died were replaced, but those replaced after the first month were not used in later analysis. Mortality after two seasons was $18 \%$ at Jepson Prairie and was caused primarily by activity of gophers (Thomomys bottae). Mortality after three seasons was $4 \%$ at the Agronomy Farm; one low-density plot was damaged and removed from the experiment.

At the Agronomy Farm, we established three blocks in a full factorial design consisting of three neighborhood manipulations and three target densities $(n=27$ plots). The plots were composed of four rows of seven transplants with the inner ten plants used as experimental targets. The spacing between transplants was 4 $\mathrm{cm}, 8 \mathrm{~cm}$, and $12 \mathrm{~cm}$ for the three densities, respectively, resulting in total plot areas of $288 \mathrm{~cm}^{2}, 1152$ $\mathrm{cm}^{2}$, and $3456 \mathrm{~cm}^{2}$. The three neighborhoods were (1) no manipulation of neighbor density (unweeded), (2) weeded of all nontarget vegetation in the first year only and unweeded for the next two years, or (3) weeded in the first two years and unweeded in the final year. In all weeded plots, the weed biomass was replaced on the soil surface to reduce differences between treat- ments due to evaporative loss from exposed soil. By using the weeding treatment, we hoped to assess the effects of nonnative annuals on performance of $N$. pulchra at different stages in its establishment. Admitted$1 y$, in the final year there was no way to assess cumulative neighborhood effects without a continuously weeded control.

At Jepson Prairie, the experimental design was modified due to the heterogeneity of the mound and intermound topography and to address slightly different questions. We established five blocks in a full factorial design consisting of two neighborhood manipulations and three target densities in both mound and intermound locations ( $n=60$ plots). The vernal pool topography of Jepson Prairie strongly affects species distribution patterns and productivity (described above and see also Holland and Jain [1988], Dyer et al. [1996], Dyer and Rice [1997]). Thus, each set of mound plots was paired with an adjacent set of intermound plots to investigate the interactive effects of soil depth and neighborhood on $N$. pulchra performance. The neighborhood manipulations were either unweeded or full removal of all nontarget vegetation for two years. Plot densities were the same as for the Agronomy Farm. The experiment was terminated after $2 \mathrm{yr}$ due to excessive gopher disturbance.

In both experiments, plots were planted in February 1993 shortly after herbicide (glyphosate) was applied to kill annual vegetation in noncontrol plots. In subsequent years removal of annual seedlings was done by hand.

Growth measurements.-We measured one growth parameter (basal diameter) and one measure of reproductive output (culm production). Vegetative growth of nonrhizomatous bunchgrasses originates from basal buds, such that basal diameter increases with plant growth. The basal diameters of all living target plants $(n=10$ plants per plot) were measured in early July 
of each year using a digital caliper. Three percent of the plants at both sites were irregularly shaped and calculations of their areas were made from perpendicular measurements of the plant base (see Dyer and Rice 1997). After the third season at the Agronomy Farm, plants in high-density plots had grown so closely together that individual basal measurements were not possible and culm counts were based on the plot mean. Flowering culms were counted on every target plant, although in the case of herbivory by rodents (Jepson Prairie) culms were counted as present if the base of the stalk remained. Because culms were removed for analysis from half of the target plants, all plants in each plot were clipped to a height of $\sim 10 \mathrm{~cm}$ after all measurements were completed in July of each year.

In spring 1996, basal diameter was measured and nonreproductive aboveground biomass was collected (clipped at 3-cm height) from 30 target plants representing a range of plant sizes in plots that had been previously weeded These data were used to estimate the relationship between plant basal area and aboveground biomass for N. pulchra at the Agronomy Farm.

Soil moisture.-Access tubes (5-cm diameter PVC [polyvinyl chloride] plastic) for a soil moisture probe (Sentry A200, Troxler Electronics Laboratories, Research Triangle Park, North Carolina) were installed in late January 1993 in the center of all medium- and lowdensity plots at both sites ( $n=18$ tubes at the Agronomy Farm and $n=40$ tubes at Jepson Prairie). High density plots were too small and the plants too close together to accommodate an access tube without changing the character of the plot.

From March 1993, soil moisture data were collected at weekly intervals throughout each growing season, and with periodic readings from August to January. At the Agronomy Farm, soil moisture readings were taken at $15,30,60,90,120,150$, and $180 \mathrm{~cm}$ depths. For this analysis, only the $60-$ and $120-\mathrm{cm}$ data are shown graphically. In the shallower soils of Jepson Prairie, a particular interest was the comparison between mound and intermound locations. Therefore, soil moisture data were collected only at 15 and $30 \mathrm{~cm}$ in both locations although a $30-\mathrm{cm}$ depth in the intermound is well within the underlying clay layer.

Soil moisture data from the probes posed analytical difficulties for various reasons, belowground heterogeneity being chief among them, and the interactive effects of perennial plants growing over multiple seasons constituted a further complication. We chose to standardize data from each depth within each plot relative to the range of readings recorded in each block (or split block at Jepson Prairie) over the course of each experiment. This yielded values from 1 to $100 \%$, representing what we term "percentage relative available soil moisture" or, specifically, the soil water that target plants and annual neighborhoods extracted over the course of the experiments. From each growing season, we chose only the series of data points that rep- resented the period of soil moisture reduction. We used these subsets of the data to estimate the timing, rate, and duration of soil moisture reduction. For the shallowest soils and depths, soil moisture reduction occurred mainly during the first 5-10 wk of the growing season; for the lowest soil depths at the Agronomy Farm, no detectable period of reduction was observed and we used the last five data points of the season.

Light availability. - Photosynthetically active radiation was measured $1.5 \mathrm{~cm}$ above the soil surface within each plot and above the canopy of each plot using the distal $20 \mathrm{~cm}$ of a sunfleck ceptometer (Decagon Devices, Pullman, Washington, USA). Each soil surface reading was standardized as a percentage of full sunlight to estimate within-plot light availability. Each plot was sampled at midday seven times from 14 February to 11 June during the 1994 growing season.

Data analysis.-Plant response data from the Agronomy Farm were analyzed as a split-plot design with weeding treatment as a main plot factor and planting density as a subplot factor. At Jepson Prairie, the data were analyzed as a split-split-plot design with topographic location (soil depth) as the main plot factor, weeding treatment as a subplot factor, and planting density as a sub-subplot factor. Plot means for growth (basal diameter in millimeters) and reproductive effort (number of culms) of $N$. pulchra targets were analyzed first with MANOVA, then separately with ANOVAs (Scheiner 1993). All analyses were performed with SAS 6.10 for Windows (SAS Institute, Cary, North Carolina, 1994).

We analyzed six variables related to soil moisture reduction for each year. They were: (1) START, the day of the year when soil moisture reduction began; (2) INITIAL, the soil moisture value $(\%)$ on the START date; (3) STOP, the day of the year when the data indicated no further reduction of soil moisture; (4) FINAL, the soil moisture value $(\%)$ on the STOP date; (5) DURATION, the length in days of the period of soil moisture reduction between the START and STOP dates; and (6) SLOPE, the mean rate of soil moisture reduction calculated from the START, STOP, and DURATION values. All variables were found to be highly correlated; we used only SLOPE and DURATION in MANOVA and protected ANOVA (JMP 3.2, SAS Institute, Cary, North Carolina, 1997) to assess effects of treatments on soil moisture reduction. The INITIAL variable was used to check for systematic differences in soil moisture values at the beginning of the experiment in 1993 and no differences between treatments were found.

The soil moisture and light data were standardized as described above, but no other data transformations were made. For each analysis, data were examined as repeated measures between years where appropriate and we used Roy's greatest root as the statistic for testing treatment effects (Scheiner 1993). Because of the differences in vegetation, soils, and experimental 
TABLE 1. Analysis of variance of basal diameter and numbers of culms of the bunchgrass Nassella pulchra at the Agronomy Farm (Yolo County, California) in a study of competition between the native bunchgrass and nonnative annual grasses.

\begin{tabular}{|c|c|c|c|c|c|c|c|c|}
\hline \multirow[b]{2}{*}{ Treatment } & \multirow[b]{2}{*}{ df } & \multicolumn{2}{|c|}{1993} & \multicolumn{2}{|c|}{1994} & \multicolumn{2}{|c|}{1995} & \multirow{2}{*}{$\begin{array}{c}\text { Repeated } \\
\text { measures } \\
\text { (MANOVA) }\end{array}$} \\
\hline & & $\begin{array}{l}\text { Diameter } \\
(\mathrm{mm})\end{array}$ & $\begin{array}{c}\text { Culms } \\
\text { (no.) }\end{array}$ & $\begin{array}{l}\text { Diameter } \\
(\mathrm{mm})\end{array}$ & $\begin{array}{l}\text { Culms } \\
\text { (no.) }\end{array}$ & $\begin{array}{l}\text { Diameter } \\
\quad(\mathrm{mm})\end{array}$ & $\begin{array}{c}\text { Culms } \\
\text { (no.) }\end{array}$ & \\
\hline Weeding & 2 & $85.38 * * *$ & $14.18 *$ & $37.20 * *$ & $16.50 *$ & $26.85^{* *}$ & $11.48^{*}$ & $14.07(2,4) *$ \\
\hline Density & 2 & $19.43 * * *$ & $11.27 * *$ & $19.41 * * *$ & $16.07 * * *$ & 1.84 & 2.00 & $8.09(2,7) *$ \\
\hline $\begin{array}{l}\text { Weeding } \times \text { density } \\
(\text { Error df, MSE) }\end{array}$ & 4 & $\begin{array}{c}2.62 \\
(11,6.047)\end{array}$ & $\begin{array}{c}3.35^{*} \\
(11,2.584)\end{array}$ & $\begin{array}{c}5.30^{*} \\
(11,28.924)\end{array}$ & $\begin{array}{r}6.05 * * \\
(11,7.114)\end{array}$ & $\begin{array}{c}4.63 \dagger \\
(7,22.921)\end{array}$ & $\begin{array}{c}1.88 \\
(7,13.832)\end{array}$ & $2.31(2,7)$ \\
\hline
\end{tabular}

Notes: Treatment factors are weeding of annual biomass (interspecific competitors) and planting density (intraspecific effect). $F$ values are followed by level of significance. Repeated-measures values are Roy's greatest root (Scheiner 1993) followed by degrees of freedom (df) in parentheses. In 1995, basal diameter values were not measurable in high-density plots and culm numbers were from the plot mean.

$* P<0.05$; ** $P<0.01$; *** $P<0.001$.

$\dagger P=0.052$.

design, no direct statistical comparisons were made between the Agronomy Farm and Jepson Prairie.

\section{RESULTS}

\section{Agronomy Farm}

Growth and reproduction.-Nassella pulchra growth was significantly greater in weeded plots than in unweeded plots and strongly density dependent (Table 1, Fig. 1A-C). Differences in culm production followed the same pattern and were also strongly density dependent (Table 1, Fig. 1D-F). However, in unweeded plots, planting density had no detectable effect on growth or culm production in any year. Compared to unweeded plots, basal diameter increase in weeded plots was about two to three times greater and culm production was up to 10 times greater in all three years. Reproductive allocation appeared to be more sensitive to annual neighbors than did vegetative growth (Fig. 1). In addition, vegetative growth was not affected by cessation of weeding after $1 \mathrm{yr}$, although culm production was slowed compared to plants in continuously weeded plots and this influence was carried over into the third year when no plots were weeded. This differential sensitivity to interspecific competition suggests that the annual neighborhood affects biomass allocation in $N$. pulchra in a manner that is not detected in measures of vegetative growth.

In general, however, the relationship between $N$. pulchra basal area and culm production was positive and significant ( $t$ test, $P<0.05$ for all years) and with all simple linear correlation values $r>0.94$ (data not shown). Basal area and aboveground biomass also exhibited a significant, positive linear relationship ( $t$ test, $P<0.0001, r=0.83$ ) although these data were not collected for each treatment and density.

Light availability._-Light availability was reduced by the annual neighborhood compared to weeded plots. On any given date, no significant main effects were detected for light availability although a strong block effect reflected the high degree of variability between the replicate areas. In unweeded plots, mean light availability at the soil surface decreased in spring $(<20 \%)$ and remained low in all treatments until late in the growing season (Fig. 2). Similar seasonal patterns were found in plots weeded in both years and plots weeded in the first year only although the latter had generally greater mean values. Variation in light availability was reduced both by the presence of annual grasses and by increased target plant density. A weeding $\times$ planting density interaction (repeated measures, $P<0.001$ ) resulted from the differences between high density/weeded plots (low light levels until the end of spring) and the medium and low density/weeded plots (decreasing light levels in spring months and increasing light levels in late spring) (Fig. 2b). The increase in light penetration was related to partial vegetative senescence in target plants during the summer.

Soil moisture availability.-In 1993, the three-way interaction between weeding, planting density, and soil depth (Table 2) indicated that (1) the presence of annual vegetation altered rates of soil moisture reduction, (2) soil moisture reduction by $N$. pulchra was density dependent when annual vegetation was absent, and (3) soil moisture reduction was related to treatments at depths below $60 \mathrm{~cm}$. The same patterns were evident in the drier second year (1994), but the MANOVA was not significant because the period of depletion (DURATION) was shortened. Soil moisture was also significantly affected both by weeding and by planting density in 1995; available soil moisture was reduced faster and to greater depth in weeded plots (Table 2). In general, the patterns of soil moisture depletion were similar between treatments at the $15 \mathrm{~cm}$ and $30 \mathrm{~cm}$ depths and no reduction was detected at a depth of 180 $\mathrm{cm}$.

In both the dry second year (1994) and the very wet third year (1995), the number of days over which soil moisture reduction was observed (DURATION) was not strongly related to the density or neighborhood treatments. This was probably related to the phenology of the annual vegetation, which senesced very early in the 1994 season and senesced in 1995 without appreciably affecting soil moisture. In December 1995, be- 

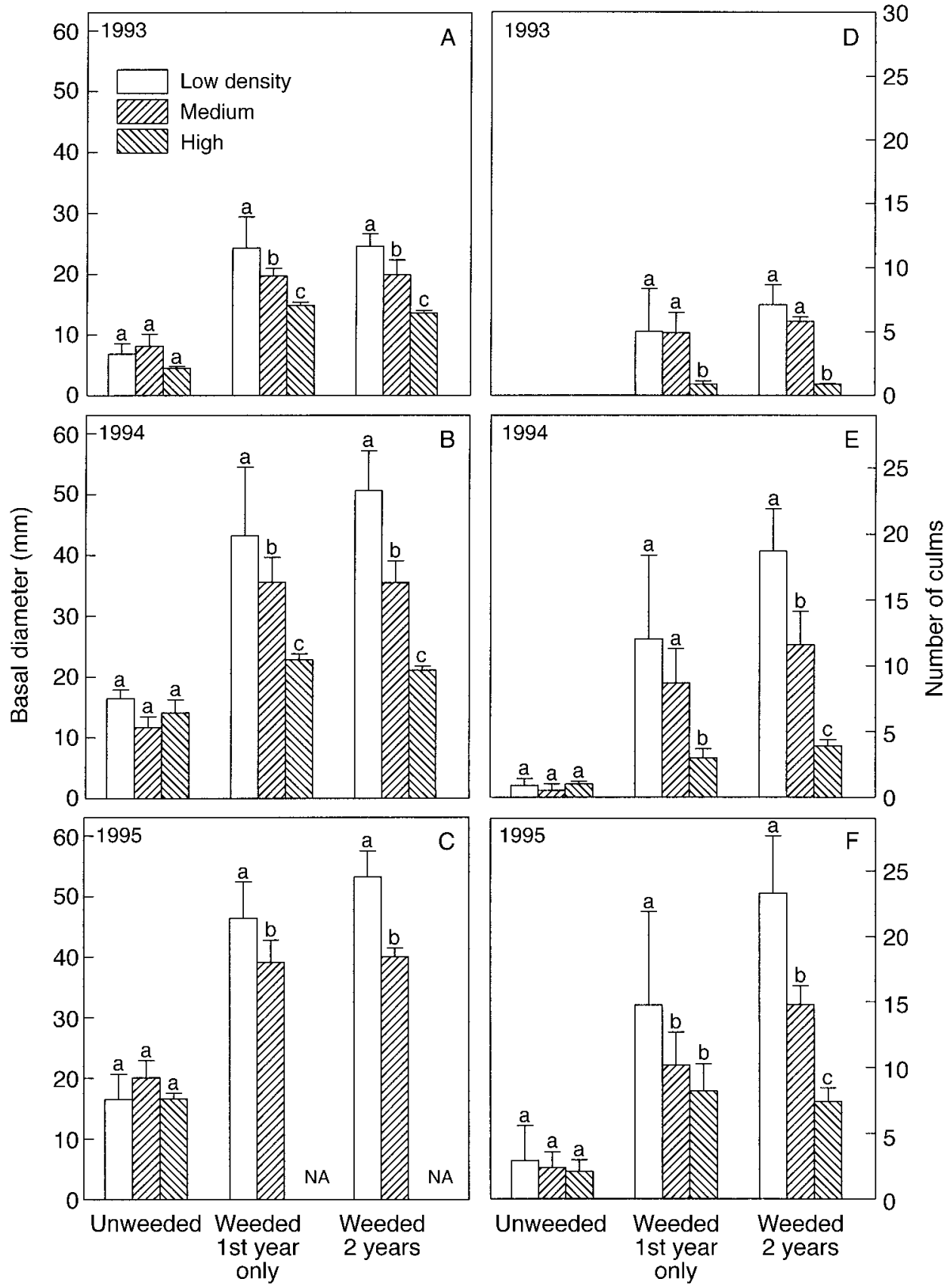

FIG. 1. Growth (basal diameter) and culm production of Nassella pulchra at the Agronomy Farm (Yolo County, California) in weeded and unweeded plots of three densities over three growing seasons. Data are means and 1 SE. Columns within treatments sharing the same letter are not significantly different. Parts A-C: The interaction between weeding and plot density is significant in the second and third years $(P<0.05)$. Basal diameter measurements could not be collected from plants in high-density plots in 1995. Parts D-F: The interaction between weeding and plot density is significant in $1993(P<0.05)$ and in $1994(P<0.01)$. The number of culms in high-density plots in 1995 was a mean value from each plot. Note that the mean size and culm number in high-density unweeded plots increased with time as small plants died.

fore the first precipitation event, water potential throughout the soil profile in unweeded areas of the study site was measured at greater than $-0.5 \mathrm{MPa}$ (J. Gerlach, unpublished data), which is near field capacity.
Annual vegetation did not reduce soil moisture below $60 \mathrm{~cm}$ depth in wet years (Fig. 3), while in the dry year depletion may have interacted with the percolation of rain water. In plots without the annual neighborhood, soil moisture reduction was significant in each year and 


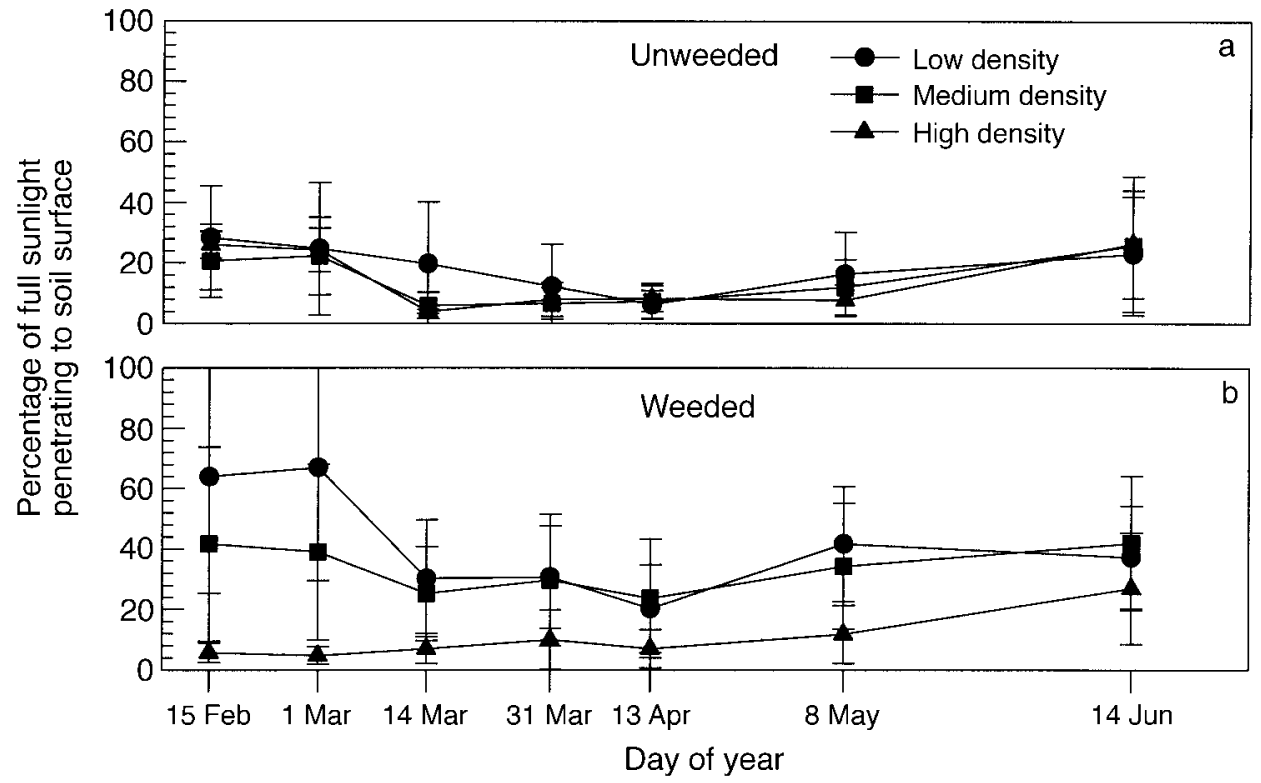

FIG. 2. Effect of the inter- and intraspecific neighborhoods on the percentage of full sunlight (mean $\pm 1 \mathrm{SE}$ ) penetrating to the soil surface over the course of the growing season in second-year Nassella pulchra plots on the Agronomy Farm (Yolo County, California). The three-way interaction of time $\times$ weeding (interspecific effect) $\times$ plot density (intraspecific effect) was significant $(P<0.001)$. For all points, $n=3$ samples, except weeded, low density plots where $n=2$ samples.

to a depth of $150 \mathrm{~cm}$ although the rate and calendar date of reduction varied between years (Fig. 3).

We found strong linear relationships when mean basal areas of the $N$. pulchra from both weeded and unweeded plots were regressed against the total reduction of soil moisture for each year. Simple correlation values for $30,60,90$, and $120 \mathrm{~cm}$ depths ranged from $r=$ 0.75 to $r=0.89$ in 1993 . However, the overall strength of the relationship declined in the next two years (correlation values were $r=0.34-0.73$ in 1994 and $r=$ $0.04-0.40$ in 1995).

\section{Jepson Prairie}

Growth and reproduction.-The three-way interaction (MANOVA) of soil depth $\times$ weeding $\times$ planting density was significant for both years $(P<0.05$ in $1993, P=0.056$ in 1994). This interaction indicated that (1) the annual neighborhood suppressed growth and, especially, culm production regardless of planting density (Figs. 4 and 5), (2) density-dependent effects on growth and culm production were very strong when the annual neighborhood was removed, and (3) the interaction between inter- and intraspecific competition was greater for plants in mound soils than in the shallower intermound soils. The disparities in N. pulchra size and reproductive output between weeded and unweeded plots became more pronounced with time (repeated measures, $P<0.05$; Table 3 ).

The effects of topographic location were significant for culm production, but not for basal diameter (Table

TABLE 2. Analysis of variance of soil moisture reduction from 30- to $180-\mathrm{cm}$ depth at the Agronomy Farm (Yolo County, California) using depletion rate (slope) and period of soil moisture reduction in days (duration) in a study of competition between the native bunchgrass Nassella pulchra and nonnative annual grasses.

\begin{tabular}{|c|c|c|c|c|c|c|}
\hline \multirow[b]{2}{*}{ Treatment } & \multicolumn{2}{|c|}{1993} & \multicolumn{2}{|c|}{1994} & \multicolumn{2}{|c|}{1995} \\
\hline & Slope & Duration & Slope & Duration & Slope & Duration \\
\hline Weeding & $35.66 * * *$ & 1.63 & $14.53 * *$ & 0.13 & $7.32 * *$ & 0.21 \\
\hline Density & $30.93 * * *$ & $4.32 \dagger$ & $11.94 * *$ & 0.00 & $15.79 * *$ & 0.11 \\
\hline Weeding $\times$ density & $23.98 * * *$ & 1.67 & $10.95 * *$ & 0.07 & $7.75 * * *$ & 0.34 \\
\hline Soil depth & $20.61 * * *$ & $21.47 * * *$ & $43.71 * * *$ & $15.13 * * *$ & $25.54 * * *$ & $11.94 * * *$ \\
\hline Weeding $\times$ soil depth & $3.88 * * *$ & $3.10 * *$ & $4.93 * * *$ & 0.97 & $21.4 *$ & $4.76^{* * * *}$ \\
\hline Density $\times$ soil depth & $5.04 * * *$ & $5.97 * * *$ & $7.24 * * *$ & 0.61 & 1.47 & 0.18 \\
\hline Weeding $\times$ density $\times$ soil depth & $3.21 * *$ & $2.22 * *$ & $4.68 * * *$ & 0.63 & 1.68 & 0.98 \\
\hline (Error df, MSE) & $(60,0.024)$ & $(60,97.77)$ & $(60,0.021)$ & $(60,152.82)$ & $(59,0.027)$ & $(59,92.78)$ \\
\hline
\end{tabular}

Notes: Treatment factors are weeding of annual biomass (interspecific competitors); planting density (intraspecific effect); and soil depth (six depths from 30 to $180 \mathrm{~cm}$ ). $F$ values are followed by levels of significance.

$* P<0.05 ; * * P<0.01 ; * * * P<0.001$.

$\dagger P=0.074$ 

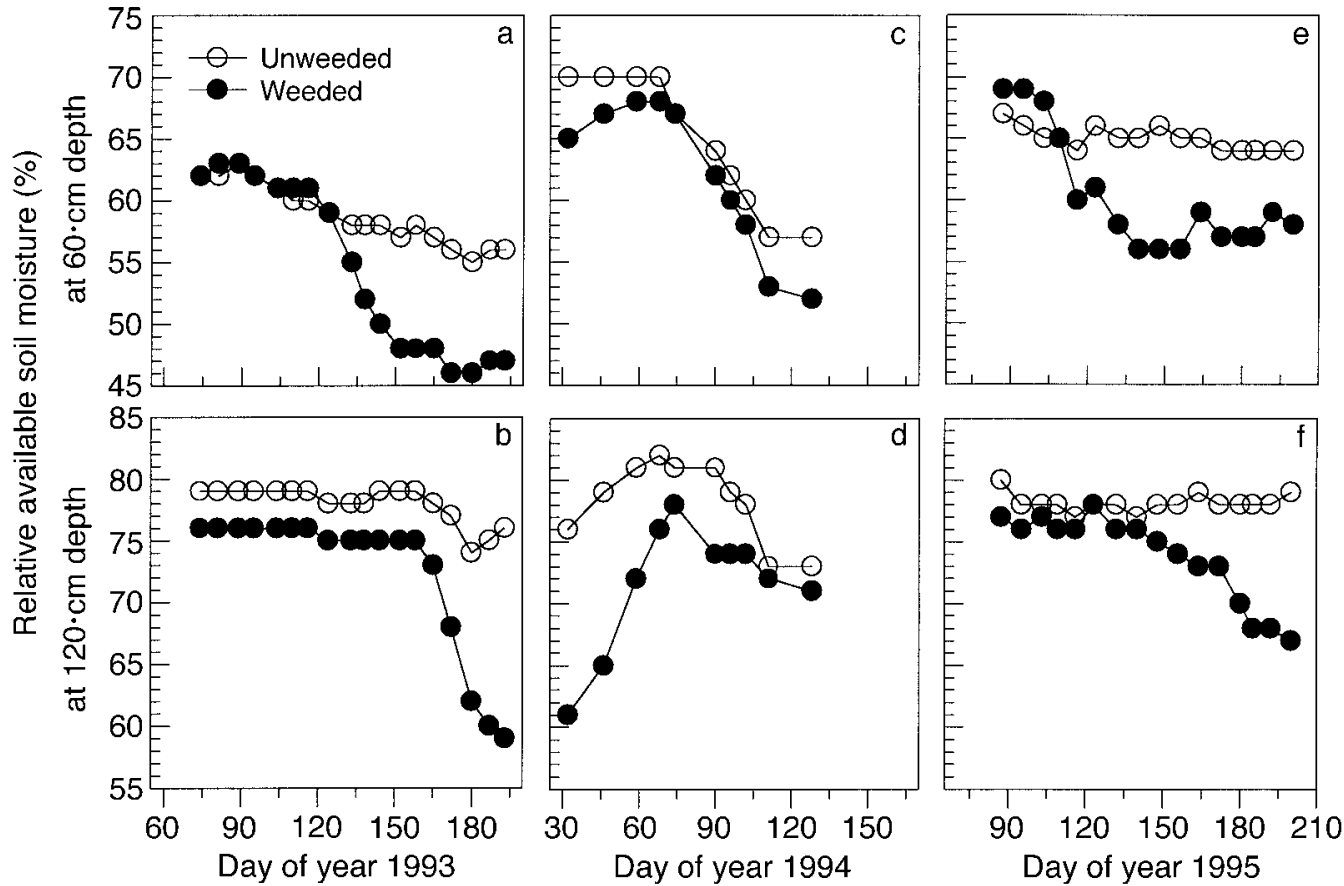

FIG. 3. Comparison between weeded and unweeded plots for reduction of relative available soil moisture (\%) at two depths in low-density plots of Nassella pulchra over three seasons at the Agronomy Farm (Yolo County, California). Parts a-b, e-f: In 1993 and 1995, both wet years, unweeded plots had little effect on soil moisture while the timing of the effect in weeded plots depended on the depth of measurement. Parts c-d: In the dry year (1994), soil moisture reductions occurred much earlier in the season but may have been confounded by reduced soil moisture recharge. For all curves, $n=3$ samples.

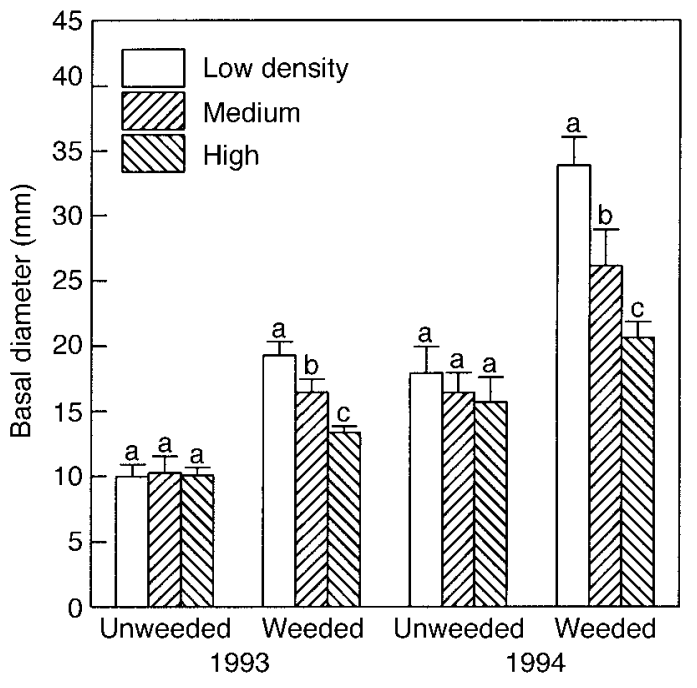

FIG. 4. Growth (basal diameter) of Nassella pulchra at the Jepson Prairie (Solano County, California) in weeded and unweeded plots of three densities over two growing seasons (means and $1 \mathrm{SE}$ ). The interaction between weeding and plot density is significant in $1993(P<0.001)$ and in $1994(P<$ 0.01 ). No effect of topographic location (soil depth) on vegetative growth was found in either year and results are combined. Columns within treatments sharing the same letter are not significantly different.
3). Plants in the shallowest soils were not strongly affected by removal of interspecific competition in the first year, but showed a significant increase in culm production in the second year (Fig. 5).

Light availability. - The interaction between weeding and planting density varied within the growing season, but was significant during the main growth period from 28 February to 12 April ( $P<0.001$ on all dates). In unweeded plots (Fig. 6a), average light availability was lower, less variable, and not related to planting density when compared to weeded plots (Fig. 6b). In general, mean light availability in intermound plots was greater than or equal to light availability in mound soil plots (data not shown).,

Soil moisture availability.-In 1993, soil moisture values in unweeded plots declined significantly faster than in weeded plots $\left(F_{1,54}=13.43, P<0.0001\right)$ and reductions were more rapid at $15 \mathrm{~cm}$ compared to 30 $\mathrm{cm}$ depths $\left(F_{1,54}=4.03, P<0.05\right)$. The weeding $\times$ depth interaction was significant only for the SLOPE variable $\left(F_{1,54}=4.03 ; P<0.05\right.$; MANOVA: $F_{1,54}=$ $3.35, P=0.072)$. This interaction indicated that plants within unweeded plots depleted soil water more rapidly at $15 \mathrm{~cm}$ than at $30 \mathrm{~cm}$ and more rapidly overall than plants within weeded plots. Since little growth of $N$. pulchra was recorded in unweeded plots, these effects on soil moisture are attributable to the annual neighborhood. 

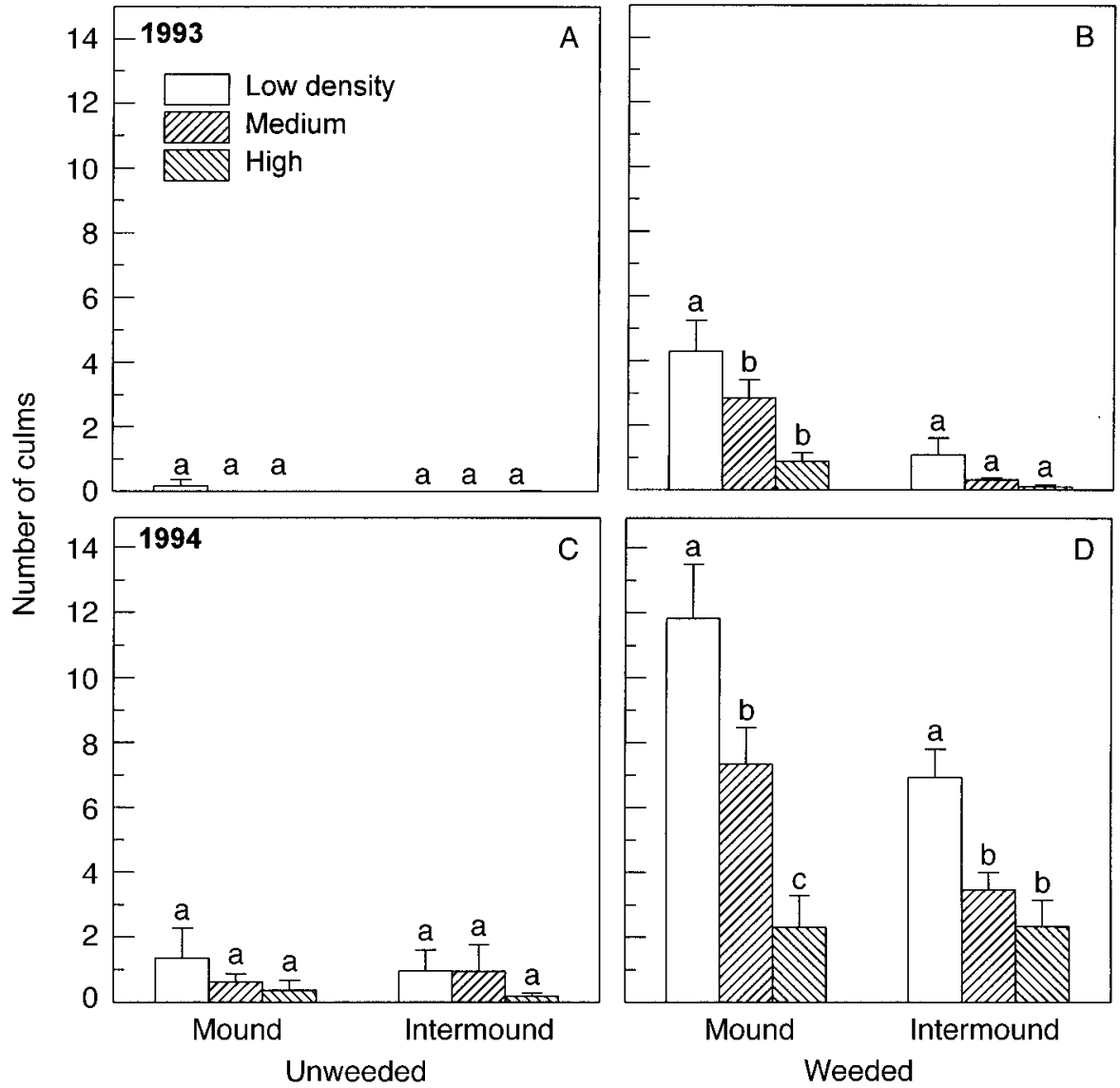

Fig. 5. Culm production of Nassella pulchra at the Jepson Prairie (Solano County, California) in weeded and unweeded plots of three densities over two growing seasons (means and $1 \mathrm{SE}$ ). The three-way interaction of topographic location (soil depth $) \times$ weeding (interspecific effect) $\times$ plot density (intraspecific effect) was significant in $1993(P<0.05)$ and in 1994 $(P=0.065)$. Parts A and C: No effect of planting density was found in unweeded plots. Parts B and D: Plants in weeded intermound plots did not show a release from interspecific competition until the second growing season. Columns within treatments sharing the same letter are not significantly different.

TABLE 3. Analysis of variance of basal diameter and numbers of culms of the bunchgrass Nassella pulchra at the Jepson Prairie (Solano County, California) in a study of competition between the native bunchgrass and nonnative annual grasses.

\begin{tabular}{|c|c|c|c|c|c|c|}
\hline \multirow[b]{2}{*}{ Treatment } & \multirow[b]{2}{*}{$\mathrm{df}$} & \multicolumn{2}{|c|}{1993} & \multicolumn{2}{|c|}{1994} & \multirow{2}{*}{$\begin{array}{c}\text { Repeated } \\
\text { measures } \\
\text { (MANOVA) }\end{array}$} \\
\hline & & Diameter $(\mathrm{mm})$ & Culms (no.) & Diameter $(\mathrm{mm})$ & Culms (no.) & \\
\hline Topographic location & 1 & $8.76^{*}$ & $14.28 *$ & 5.10 & $17.97 *$ & $3.78(1,4)$ \\
\hline Weeding & 1 & $54.40 * * *$ & $40.26 * * *$ & $124.86 * * *$ & $176.87 * * *$ & $95.49(1,8) * * *$ \\
\hline Topography $\times$ weeding & 1 & 2.20 & $18.87 * *$ & $5.24 \dagger$ & $15.73 * *$ & $2.53(1,8)$ \\
\hline Density & 2 & $8.58 * * *$ & $18.03 * * *$ & $13.14 * * *$ & $34.08 * * *$ & $1.67(2,30)^{* * *}$ \\
\hline Topography $\times$ density & 2 & 0.59 & $6.21 * *$ & 0.21 & 2.86 & $0.07(2,30)$ \\
\hline Weeding $\times$ density & 2 & $9.13 * * *$ & $15.71 * * *$ & $6.62 * *$ & $21.11 * * *$ & $4.72(2,30)^{*}$ \\
\hline $\begin{array}{l}\text { Topography } \times \text { weeding } \\
\times \text { density } \\
(\text { Error df, MSE })\end{array}$ & 2 & $\begin{array}{c}0.35 \\
(32,4.92)\end{array}$ & $\begin{array}{c}4.76^{*} \\
(32,0.36)\end{array}$ & $\begin{array}{c}0.43 \\
(30,24.0)\end{array}$ & $\begin{array}{c}3.01 \ddagger \\
(30,2.24)\end{array}$ & $0.76(2,30)$ \\
\hline
\end{tabular}

Notes: Treatment factors are topographic effect (mound and intermound soil depth); weeding of annual biomass (interspecific competitors); and planting density (intraspecific effect). $F$ values are followed by level of significance. Repeated-measures values are Roy's greatest root (Scheiner 1993) with degrees of freedom (df) in parentheses.

$* P<0.05 ; * * P<0.01 ; * * * P<0.001$

$\dagger P=0.051$

$\ddagger P=0.065$ 


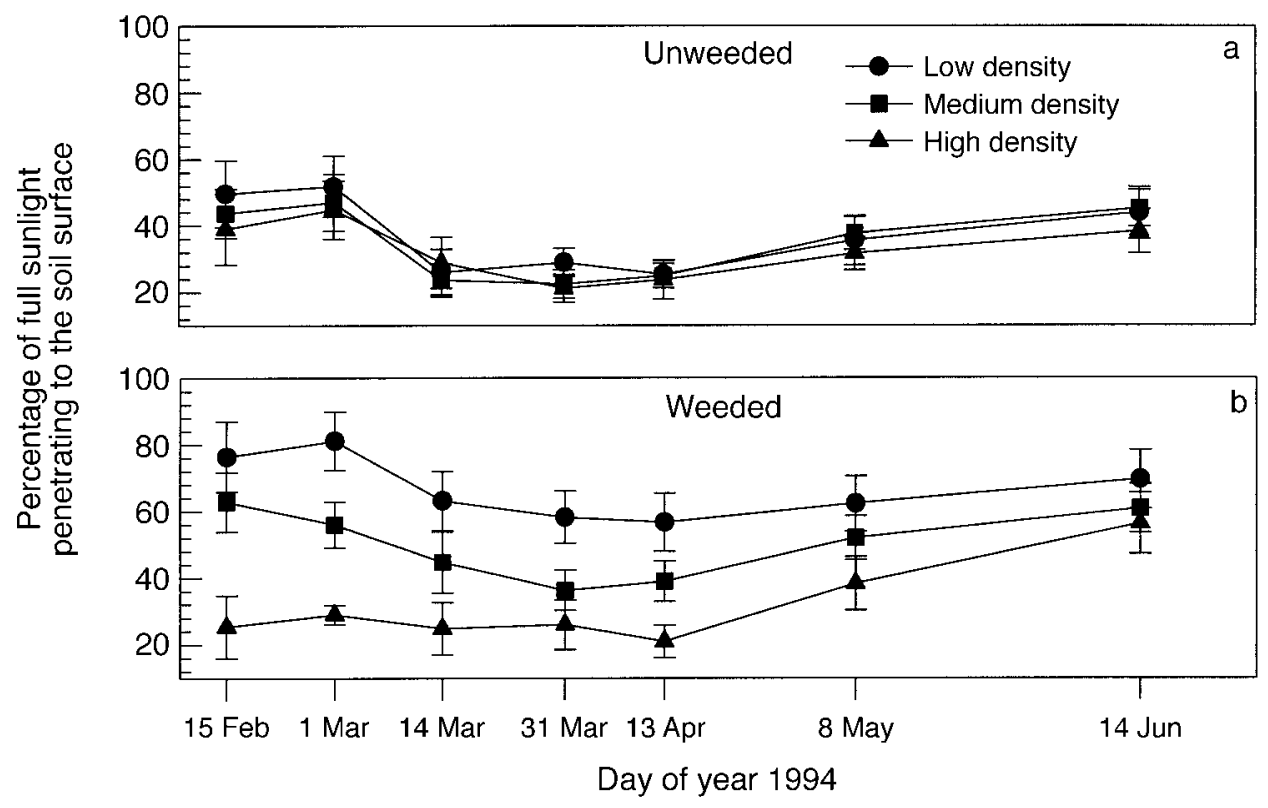

FIG. 6. Effects of the inter- and intraspecific neighborhoods on the percentage of full sunlight (mean $\pm 1 \mathrm{SE}$ ) penetrating to the soil surface over the course of the growing season in second-year Nassella pulchra plots at Jepson Prairie (Solano County, California). The three-way interaction of time $\times$ weeding (interspecific effect) $\times$ plot density (intraspecific effect) was significant $(P<0.05)$. For all points, $n=4$ or 5 samples.

In general, the soil depth limitation at this site resulted in soil moisture being depleted at similar rates in both mound and intermound locations and regardless of planting density. In the low rainfall year (1994), the slopes of the depletion curves were steep and identical for all plots at both depths and no significant treatment effects or interactions were detected.

\section{DISCUSSION}

In our experiments at Jepson Prairie and the Agronomy Farm, we found very strong negative effects of the annual grass neighborhood on vegetative and, especially, reproductive growth of Nassella pulchra. This negative influence continued into the third season after planting although whether it represented residual effects from the first year or a continued effects from the annual community was not investigated. The results suggest that the annual neighborhood greatly modified resource availability both above and below ground although the relative importance of the two resource pools may vary temporally. Target plants were suppressed similarly by the annual neighborhood in both soil depths at the Jepson Prairie and in the deep soil of the Agronomy Farm. At both sites, density-dependent (intraspecific) effects of the target plants were found only when the annual neighborhood was removed. At the highest planting density, the effect of intraspecific competition on growth was nearly as strong as the interspecific effect of the annual neighborhood.

The annual neighborhood decreased light availability for $N$. pulchra while simultaneously affecting below- ground soil water availability; the two components of competition were tightly linked and not easily separated. In these experiments, we did not try to separate the effects of annuals on above- and belowground resources. Instead, we focused on the overall effects of the annual neighborhood on the growth of perennial seedlings and how changes in resource availability were related to effective rooting depth. The following discussion, therefore, will consider first the influences of annuals on aboveground performance of $N$. pulchra and second, the effects on belowground resource availability.

\section{Competition and aboveground resource availability}

At both the Agronomy Farm and the Jepson Prairie, aboveground performance of Nassella pulchra was greatly reduced in plots with interspecific competition and in weeded plots with high densities of intraspecific competitors. These plots were characterized by relatively low light availability during the second growing season. In unweeded plots, little or no culm production and very little basal growth was recorded in both experiments in the first year. By the end of the study, plants in unweeded plots at both sites had doubled in size, but culm production remained disproportionately low. These data indicated that reproductive output in $N$. pulchra was more sensitive to competition than was vegetative growth at both sites. Culm production also was more sensitive to the physical stress associated with the restricted belowground growing conditions at Jepson Prairie, regardless of the competitive environment. In weeded plots, both veg- 
etative growth and culm production were strongly affected by intraspecific competition, but never to the same degree as in unweeded plots except at the highest N. pulchra density.

At Jepson Prairie, the effect of the light environment on the growth of the target plants probably interacted with the size of the belowground resource pool. Deeper soils support greater biomass production by annual grasses (McConnaughay and Bazzaz 1987) resulting in a less favorable light environment for $N$. pulchra. Thus, the lack of any strong differences in growth between plants in mound and intermound plots may be due to the more favorable light environment in the intermound. This may explain why $N$. pulchra plants in unweeded plots at the Agronomy Farm (where annual biomass was very high) grew more slowly than plants in unweeded plots at Jepson Prairie (where aboveground annual biomass was much less). Midseason light levels at the soil surface were $\sim 10 \%$ of full sunlight in unweeded plots at the Agronomy Farm, but $\sim 20 \%$ in unweeded plots at Jepson Prairie. This increase in light availability may have allowed for some compensation for the effects of restricted rooting.

To predict more accurately the influence of the annual community on the ecosystem itself, annual estimates of biomass production should have been collected from all plots. For two reasons we did not do that in these experiments. First, we wished to investigate competitive effects over multiple seasons without unnecessary removal of aboveground biomass and litter. Second, the greatly differing phenologies of annuals and perennials require different harvest times for biomass collection and that creates the possibility of affecting late-season growth patterns of the perennials after removal of the senescent annual biomass. Collection of such data would have required many more experimental plots to control for unintentional harvest effects.

\section{Belowground resource availability}

The rate of depletion of the belowground resource pool was a function both of soil depth and of aboveground community composition. Our measure of seasonal soil water reduction indicated that soil resources available to $N$. pulchra and the neighboring community were fully depleted in each of the two seasons at Jepson Prairie regardless of the weeding treatment or the soil depth. N. pulchra at Jepson Prairie were unable to escape belowground resource limitations even when interspecific competitors were removed. In contrast, although soil water resources at the Agronomy Farm were greatly reduced in the upper layers of the soil profile, especially in unweeded plots, soil water was never fully depleted below $60-\mathrm{cm}$ depth in any of the three seasons measured. Therefore, any perennial grass seedlings that attain sufficient size, such as $N$. pulchra in weeded plots at the Agronomy Farm, can potentially root below the upper soil layers and escape some of the negative influence of the annual neighborhood.

At Jepson Prairie, the strong interactive effects between topographic locations (soil depth) and planting density on aboveground growth was indicative of the general belowground resource limitations of the site. When interspecific competition was removed, N. pulchra in mound plots produced more flowering culms, while those in the shallower intermound soil did not produce culms until the second growing season. The more restrictive growing conditions in intermounds appeared to impose a shortened growing season, which was reflected in lower final basal diameter and culm numbers.

The importance of annual variability in rainfall and its effect on soil water recharge was noticeable at both sites in the dry year (1994). Soil moisture reduction was rapid and linear at the Jepson Prairie irrespective of weeding treatments and topographic location. At the Agronomy Farm, the low rainfall interacted with soil water recharge such that the deeper layers in the weeded plots, in which soil water had been reduced the previous growing season, were slower to return to field capacity than the same depths in unweeded plots (Fig. 3). All plots were fully recharged at the beginning of the very wet third year. Also soil water reduction was initiated earlier in the year at both sites in the drier year compared to the wetter years.

At the Agronomy Farm, N. pulchra were unable to escape suppression in plots with intact annual neighborhoods and gained access to deep soil moisture only when competition, particularly for light, was alleviated by removal of interspecific aboveground biomass. Spatial and temporal partitioning of belowground resources has been predicted to be a method by which species may alleviate interspecific competition (Parrish and Bazzaz 1976, Berendse 1979, 1982, Aarssen 1983; C. S. Brown and K. J. Rice, unpublished data). In the California grasslands, the depth to which roots of a perennial grass extend may determine the extent to which it reduces belowground competition with annual species (Harris 1967, Holmes and Rice 1996). Therefore, access to soil moisture reserves at $>1 \mathrm{~m}$ depth may help promote survival of perennial grasses in annual grasslands (Holmes and Rice 1996). In this experiment, however, the ability of $N$. pulchra target plants to escape from belowground competition depended on a reduction in aboveground competition. The minimum reduction of aboveground annual biomass needed by $N$. pulchra for competitive release belowground remains unexplored and will undoubtedly interact with soil quality and seasonal climatic variation.

Relative available soil moisture was greatly reduced each growing season to a depth of $30 \mathrm{~cm}$ at both the Agronomy Farm and Jepson Prairie. In the shallow Jepson Prairie soil, total plant growth reflected rooting restriction, greater soil moisture limitation, and, pre- 
sumably, a higher degree of physiological stress. Depletion patterns in weeded plots at the Agronomy Farm showed that target plants had some proportion of root biomass extending into the lower soil levels and thus had continuous access to soil moisture throughout the relatively longer growing season (see also Holmes and Rice [1996]). Thus, the degree of water stress experienced by $N$. pulchra in the two experiments was related to total soil water availability which, in turn, was related to soil depth.

\section{Effects of nonnative annual species on resource availability and $\mathrm{N}$. pulchra performance}

We found that above- and belowground resource availability was strongly reduced by the nonnative annual community and this reduction resulted in suppressed growth of $N$. pulchra. Resource requirements and patterns of resource use by annual grasses are clearly different from perennial grasses. Decreased root to shoot ratios of annuals relative to perennial species result in rapid canopy development and soil moisture depletion in upper soil layers (Jackson and Roy 1986, Gordon et al. 1989, Holmes and Rice 1996). With high relative densities and high relative growth rates, annual grasses can change the resource availability in the grassland both spatially and temporally. Therefore, life history patterns in contrast to those of bunchgrasses have enabled annual grasses to become dominant. In particular, bunchgrasses have low allocation to shoot biomass at the seedling stage and relatively inflexible timing of phenological stages (Jackson and Roy 1986).

Annual grass species in California can form dense canopies each winter and spring that greatly reduce light penetration to the soil surface and this interference competition (sensu Harper 1965) reduces growth of seedlings of native species. Consequently, dense stands of annual grasses suppress establishment (Bartolome and Gemmill 1981, Dyer et al. 1996) and aboveground growth (Dyer and Rice 1997) of N. pulchra and reduce a seedling's ability to develop the root system necessary to gain access to deep soil moisture before the summer drought.

Both aboveground competition for light and belowground competition for water appear to be important processes in the inland California grasslands. The relative importance, however, of the two forms of resource competition may be directly related to the species composition of the grassland. The importance of competition in the summer for soil moisture has been cited as a critical factor in mediterranean climates (Kay and Owen 1970, Evans and Young 1972, Jackson 1985, Jackson and Roy 1986) and the potential for a temporal shift in soil resource availability associated with increased abundance of annual vegetation has been proposed (White 1967, Jackson and Roy 1986, Gordon et al. 1989, Holmes and Rice 1996). The suppression of $N$. pulchra growth in spring and its subsequent inability to gain access to deep soil moisture in summer leads us to agree that the basic growing environment of the inland California grasslands has changed with the invasion of nonnative annual species. However, annuals have shifted not only the primary limiting resource from water (belowground) to light (aboveground), but have shifted the timing of competition temporally from summer to winter and spring. Given growth characteristics in which slow aboveground growth and increased root proliferation in winter prepare bunchgrasses for belowground resource limitations in summer (Jackson and Roy 1986), we further conclude that $N$. pulchra is at a competitive disadvantage within the climatic regime in which it evolved.

\section{Implications for conservation and future invasions}

Within deep soils in the California grasslands, the senescence of winter annuals in April and May and the general absence of summer annual and woody perennial species appears to result in residual soil water resources below $60 \mathrm{~cm}$. This phenomenon has been predicted based on circumstantial evidence (i.e., the loss of perennial grasses from the grasslands) (Biswell 1956, Bartolome 1979, Heady et al. 1992), but has not been demonstrated experimentally until recently (Borman et al. 1992, Holmes and Rice 1996).

In terms of the future of the inland California grasslands, evidence for residual soil moisture under stands of senescent annual vegetation, and the low relative competitive ability of bunchgrass seedlings, like those of N. pulchra (Holmes and Rice 1996), implies a potential for further invasion of California grasslands by nonnative species capable of exploiting the belowground resources. Based on evidence from this study, we predict that these species would be summer annual or perennial species capable of rooting to depths of $\geq 1$ $\mathrm{m}$. An example of such a species might be the nonnative thistle Centaurea solstitialis L., a summer annual with an extensive and deep rooting system that has greatly expanded its range in recent years (Gerlach and Rice 1996). Within annual grasslands invaded by $C$. solstitialis, residual soil moisture levels have been shown to be much lower than in adjacent uninvaded annual grassland (Borman et al. 1992, Gerlach and Rice 1996).

High densities of nonnative annual grasses in the inland California grassland have changed not only the seasonal growth dynamics of the native species (Gordon et al. 1989), but also the long-term prospects for successional change (Stromberg and Griffin 1996). Although the historical role of native annual grasses and their densities remain unknown, recent changes to basic grassland properties can be inferred (Vitousek 1990). Historically, with a greater natural abundance of perennial species, soil moisture was undoubtedly used more completely to greater depths in the grassland ecosystem. However, the widespread elimination of perennial grass species, whether by one or more factors such as agricultural conversion, overgrazing, fire suppression, drought, and invasive species, has left unuti- 
lized belowground resources that presumably represent unoccupied niche space (Crawley 1987, McConnaughay and Bazzaz 1991). Given the tenacity of many nonnative species, the composition and species interactions within the early California prairie may be of academic interest only. However, faced with (1) the potential for future invasion of aggressive nonnative species and (2) changes to overall resource availability related to the conversion of the California prairie to an annual-dominated system, the restoration of native perennial species may offer potential for reducing the likelihood of future invasions.

\section{ACKNOWLEDGMENTS}

This research was supported by grants from The Nature Conservancy (contract CARO 102692-R), a Jastro-Shields Graduate Research Scholarship (to A. R. Dyer), and a Mildred E. Mathias Student Research Grant (to A. R. Dyer). The authors wish to thank Oren Pollak, Eric Nagy, and Ken Taggard for assistance; and John Gerlach, Deborah Goldberg, Marcel Rejmanek, Mark Schwartz, Tom Miller, and two anonymous reviewers for helpful comments on earlier versions of this paper.

\section{Literature Cited}

Aarssen, L. W. 1983. Ecological combining ability and competitive combining ability in plants: toward a general evolutionary theory of coexistence in systems of competition. American Naturalist 122:707-731.

Bartolome, J. W. 1979. Germination and seedling establishment in California annual grassland. Journal of Ecology 67:273-282.

Bartolome, J. W., and B. Gemmill. 1981. The ecological status of Stipa pulchra (Poaceae) in California. Madro 28 172-184.

Bates, L. A. 1977. Soil survey of Solano County, California. U.S. Department of Agriculture Soil Conservation Service.

Belcher, J. W., P. A. Keddy, and L. Twolan-Strutt. 1995. Root and shoot competition intensity along a soil depth gradient. Journal of Ecology 83:673-682.

Berendse, F. 1979. Competition between plant populations with different rooting depths I. Theoretical considerations Oecologia 43:19-26.

. 1982. Competition between plant populations with different rooting depths III. Field experiments. Oecologia 53:50-55.

Biswell, H. H. 1956. Ecology of California grasslands. Journal of Range Management 9:19-24.

Borman, M. M., D. E. Johnson, and W. C. Krueger. 1992. Soil moisture extraction by vegetation in a Mediterranean/ maritime climatic region. Agronomy Journal 84:897-904.

Crawley, M. J. 1987. What makes a community invasible? Pages 429-453 in A. J. Gray, M. Crawley, and P. J. Edwards, editors. Colonization, succession and stability. Blackwell Scientific, Oxford, UK.

D’Antonio, C. M., and P. M. Vitousek. 1992. Biological invasions by exotic grasses, the grass/fire cycle, and global change. Annual Review of Ecology and Systematics 23: $63-87$.

Dyer, A. R., H. C. Fossum, and J. W. Menke. 1996. Emergence and survival of Nassella pulchra in a California grassland. Madroño 43:316-333.

Dyer, A. R., and K. J. Rice. 1997. Intraspecific and diffuse competition: the response of Nassella pulchra in a California grassland. Ecological Applications 7:484-492.

Evans, R. A., and J. A. Young. 1972. Competition within the grass community. Pages 230-46 in V. B. Youngner and
C. M. McKell, editors. The biology and utilization of grasses. Academic Press, New York, New York, USA.

Evans, R. A., and J. A. Young. 1989. Competition and analysis of abiotic factors and their influences on vegetation. Pages 13-28 in L. F. Huenneke and H. A. Mooney, editors. Grassland structure and function: California annual grassland. Kluwer Academic, Dordrecht, The Netherlands.

Fowler, N. L. 1986. The role of competition in plant communities in arid and semiarid regions. Annual Review of Ecology and Systematics 17:89-10.

Gerlach, J. D., and K. J. Rice. 1996. Centaurea solstitialis threatens California's ecosystems. Bulletin of the Ecological Society of America 77:160.

Goldberg, D. E. 1987. Neighborhood competition in an oldfield plant community. Ecology 68:1211-1223.

- 1990. Components of resource competition in plant communities. Pages 27-49 in J. Grace and D. Tilman, editors. Perspectives on plant competition. Academic Press, San Diego, California, USA.

- 1994. Influence of competition at the community level: an experimental version of the null models approach. Ecology 75:1503-1506.

Goldberg, D. E., and K. Landa. 1991. Competitive effects and response: hierarchies and correlated traits in the early stages of competition. Journal of Ecology 79:1013-1030.

Goldberg, D. E., and A. Novoplansky. 1997. On the relative importance of competition in unproductive environments. Journal of Ecology 85:409-418.

Gordon, D. R., J. M. Welker, J. W. Menke, and K. J. Rice. 1989. Competition for soil water between annual plants and blue oak (Quercus douglasii) seedlings. Oecologia 79: 533-541.

Grime, J. P. 1979. Plant strategies and vegetation processes. Wiley, Chichester, UK.

Gulmon, S. L., N. R. Chiariello, H. A. Mooney, and C. C. Chu. 1983. Phenology and resource use in three co-occurring grassland annuals. Oecologia 58:33-42.

Gurevitch, J. 1986. Competition and the local distribution of the grass Stipa neomexiana. Ecology 67:46-57.

Harper, J. L. 1965. The nature and consequence of interference amongst plants. XI International Congress of Genetics 2:465-482.

Harris, G. A. 1967. Some competitive relationships between Agropyron spicatum and Bromus tectorum. Ecological Monographs 37:89-111.

Heady, H. A. 1988. Valley grassland. Pages 491-512 in M. G. Barbour and J. Major, editors. Terrestrial vegetation of California. Wiley Interscience, John Wiley and Sons, New York, New York, USA.

Heady, H. A., J. W. Bartolome, M. D. Pitt, G. D. Savelle, and M. C. Stroud. 1992. California prairie. Pages 313335 in R. T. Coupland, editor. Natural grasslands. Elsevier Science Publishers, Amsterdam, The Netherlands.

Hickman, J. C., editor. 1993. The Jepson Manual: higher plants of California. University of California Press, Berkeley, California, USA

Holland, R., and S. Jain. 1988. Vernal pools. Pages 515-533 in M. G. Barbour and J. Major, editors. Terrestrial vegetation of California. Wiley Interscience, John Wiley and Sons, New York, New York, USA.

Holmes, T. H., and K. J. Rice. 1996. Patterns of growth and soil-water utilization in some exotic annuals and native perennial bunchgrasses of California. Annals of Botany 78: 233-243.

Huenneke, L. F. 1989. Distribution and regional patterns of California grasslands. Pages 1-12 in L. F. Huenneke and H. A. Mooney, editors. Grassland structure and function: California annual grassland. Kluwer Academic, Dordrecht, The Netherlands.

Huntington, G. L., J. C. Wardlaw, M. Minno, W. Allardice, 
C. Monti, and A. Shen. 1981. Soil survey of the University of California Davis (Campus and adjacent lands). Department of Land, Air, and Water Resources, University of California, Davis, California, USA.

Jackson, L. E. 1985. Ecological origins of California's Mediterranean grasses. Journal of Biogeography 12:349-361.

Jackson, L. E., and J. Roy. 1986. Growth patterns of mediterannean annual and perennial grasses under simulated rainfall regimes of southern France and California. Acta Oecologica/Oecologia Plantarum 7:191-212.

Jackson, L. E., R. B. Strauss, M. K. Firestone, and J. W. Bartolome. 1988. Plant and soil nitrogen dynamics in California annual grassland. Plant and Soil 110:9-17.

Kadmon, R., and A. Shmida. 1995a. Competition in a variable environment: an experimental study in a desert annual plant population. Israel Journal of Botany 39:403-412.

Kadmon, R., and A. Shmida. 1995b. Patterns and causes of spatial variation in the reproductive success of a desert annual. Oecologia 83:139-144.

Kay, B. L., and R. E. Owen. 1970. Paraquat for range seeding in cismontane California. Weed Science 18:238-243.

Keddy, P. A. 1989. Competition. Chapman and Hall, London, UK.

Knapp, A. K., and T. R. Seastedt. 1986. Detritus accumulation limits productivity of tallgrass prairie. BioScience 32:662-668

Major, J. 1988. California climate in relation to vegetation Pages 11-74 in M. G. Barbour and J. Major, editors. Terrestrial vegetation of California. Wiley Interscience, New York, New York, USA.

McConnaughay, K. D. M., and F. A. Bazzaz. 1991. Is physical space a soil resource? Ecology 72:94-103.

McNaughton, S. J. 1968. Structure and function in California grasslands. Ecology 49:962-972.

Miller, T. E., and P. A. Werner. 1987. Competitive effects and responses between plant species in a first-year old-field community. Ecology 68:1201-1210.

Newman, E. I. 1973. Competition and diversity in herbaceous vegetation. Nature 244:310.

Parrish, J. A. D., and F. A. Bazzaz. 1976. Underground niche separation in successional plants. Ecology 57:1281-1288.
Rice, K. J. 1989. Competitive interactions in California annual grasslands. Pages 59-71 in L. F. Huenneke and H. A. Mooney, editors. Grassland structure and function: California annual grassland. Kluwer Academic, Dordrecht, The Netherlands.

Scheiner, S. M. 1993. MANOVA: multivariate response variables and multispecies interactions. Pages 94-112 in S. M. Scheiner and J. Gurevitch, editors. Design and analysis of ecological experiments. Chapman and Hall, New York, New York, USA

Stromberg, M. R., and J. R. Griffin. 1996. Long-term patterns in coastal California grasslands in relation to cultivation, gophers, and grazing. Ecological Applications 6:11891211.

Talbot, M. W., H. H. Biswell, and A. L. Hormay. 1939. Fluctuations in the annual vegetation of California. Ecology 20: 394-402.

Tilman, D. 1988. Plant strategies and the dynamics and structure of plant communities. Princeton University Press, Princeton, New Jersey, USA.

Turitzen, S. N. 1995. Canopy structure and potential light competition in two adjacent annual plant communities. Ecology 59:161-167.

Van Auken, O. W., J. K. Bush, and D. D. Diamond. 1994. Changes in growth of the $\mathrm{C}_{4}$ grasses (Schizachyrium scorparium and Paspalum plicatulum) in monoculture and mixture: influence of soil depth. American Journal of Botany 81:15-20.

Vitousek, P. M. 1986. Biological invasions and ecosystem properties: can species make a difference? Pages 163-167 in $\mathrm{H}$. A. Mooney and J. Drake, editors. Biological invasions of North America and Hawaii. Springer-Verlag, New York, New York, USA

. 1990. Biological invasions and ecosystem processes: towards an integration of population biology and ecosystem studies. Oikos 57:7-13.

Weaver, J. E., and N. W. Rowland. 1952. Effects of excessive natural mulch on development, yield, and structure of native grassland. Botanical Gazette 114:1-19.

White, K. L. 1967. Native bunchgrass (Stipa pulchra) on Hastings Reservation, California. Ecology 48:949-955. 